\title{
EDITORIALS \\ The interaction between genetics and epidemiology: the puzzle and its pieces
}

\author{
EDITORIALI \\ L'interazione fra genetica ed epidemiologia: il puzzle e le tessere
}

\author{
MIRELLA RUGGERI, Guest Editor \\ and MICHELE TANSELLA, Editor
}

The aim of the three Editorials published in this issue of EPS is to discuss the potential of the interaction between genetics and epidemiology, not only for psychiatric research but also for clinical practice.

Optimal clinical practice can be considered the capacity to design treatments based on the best available knowledge of a puzzle that comprises the factors that cause and interfere with the onset and course of mental disorders. Research is then the process by which pieces of that puzzle are assembled without having the benefit of the box-top picture of the completed puzzle; it takes many separate pieces of the "puzzle" to reach an understanding of the entire scene (Hough \& Ursano, 2006). These pieces represent different types of data, often obtained using diverse approaches and techniques. The challenge of the researcher is to imagine each of the missing pieces before actually having them in hand. In solving puzzles, the shape of the pieces is not the only limitation that needs to be satisfied; one must also ensure that the final picture has to make sense. In some instances, the quality of the research is judged by the number of ways a piece of data integrates into and coalesces the rest of the puzzle. The multidimensionality of scientific enquiries makes it essential that as many different pieces of the puzzle as possible are obtained. The more that is unknown about the puzzle, the more pieces one needs. In our opinion, this example is emblematic of the key challenges that we face when addressing the interplay between biological and social sciences, and specifically the interplay between genetics and epidemiology in the understanding of psychiatric diseases.

The three Editorials in this Issue of EPS answer to three principal questions, all of which are "pieces" of a puzzle whose "box-top picture" is unclear:

i) how genetics and clinical epidemiology research can interact to sharpen our understanding of the phenotype of mental disorders, and, perhaps, help to yield more reliable classifications of mental disorders;
I tre Editoriali in questo numero di EPS mirano ad esemplificare le potenzialità dell'interazione fra genetica ed epidemiologia, non solo nell'ambito della ricerca in psichiatria ma anche per la pratica clinica.

La pratica clinica attuata in maniera ottimale richiede la capacità di mettere in atto trattamenti individualizzati che tengono conto delle migliori evidenze che derivano da un insieme di informazioni riguardanti gli aspetti che causano o interferiscono con l'insorgenza ed il decorso dei disturbi psichici. Queste informazioni possono essere considerate le tessere di un puzzle e, in qualche modo, la ricerca scientifica può essere considerata il tentativo di mettere assieme le tessere di questo puzzle senza conoscere la figura illustrata sul coperchio della scatola (Hough \& Ursano, 2006). Occorre mettere al posto giusto parecchie tessere prima di riuscire in qualche modo a comprendere la figura. E, nell'ambito della ricerca, queste tessere corrispondono spesso ai dati ottenuti con diversi approcci e metodologie. Una delle sfide dei ricercatori è immaginare quali siano i pezzi mancanti prima di averli in mano. Per far questo non occorre solo avere in mente la forma che dovrebbero avere queste tessere, ma occorre anche tener conto della plausibilità dell'immagine che esse andrebbero a formare. In alcuni casi, la qualità della ricerca può essere giudicata proprio da come una tessera si integra nel puzzle e si collega con le altre tessere. Molti quesiti scientifici non ancora risolti possono essere indagati solo mediante indagini multidimensionali, in modo da mettere al posto giusto tessere di diversa tipologia. E meno si sa di un puzzle, più sono le tessere di cui abbiamo bisogno. A noi pare che questo esempio metta in luce alcune delle sfide prioritarie che debbono essere affrontate quando si intende indagare l'interazione fra scienze biologiche e sociali e, specificatamente, il ruolo dell'interazione fra genetica ed epidemiologia nella comprensione dei disturbi psichici.

I tre Editoriali presentati in questo numero di EPS hanno l'obiettivo di rispondere a tre quesiti principali, ciascuno di questi può essere considerato una tessera di un 
ii) how data from genetics and clinical epidemiology research interact to reveal the interplay between genes and the environment and thus provide an understanding of how the environment can be modified to prevent or improve the outcome of psychiatric disorders;

iii) which contributions from various disciplines, and the specific methodologies, will allow us to comprehend the overall picture of etiopathogenesis of mental disorders and identify better treatments target.

As emphasized in this Issue's Editorial by Tosato \& Lasalvia (2009), the inconsistent results and disappointing findings of genetic research on schizophrenia arise from the intrinsic characteristics of the phenotype that is diagnosed as "schizophrenia". The failure to demonstrate the existence of a unitary disease process, has led to the conceptualization of schizophrenia as a disorder that varies its pathophysiology, clinical phenomenology and outcomes. The extent to which these components are interrelated is still largely unknown, which has hampered progresses in determining the true nature of this disorder (Peralta \& Cuesta, 2003).

These complexities also have lead to criticisms of the DSM-IV definition of schizophrenia which although it undoubtedly has increased the reliability of the diagnostic process and apparently has simplified the task for researchers, it does not provide information about the fundamental nature of schizophrenia. These shortcomings concern not only schizophrenia. In general, genetic psychiatry has suffered from confounding issues that are related to phenotypic definition and variability (Craddock et al., 2008) and from the lack of knowledge of specific neuropathological features or biomarkers and environmental influences (Kennedy et al., 2003).

As Tosato \& Lasalvia (2009) emphasise, the interaction between genetic factors and environmental characteristics (van Os et al., 2008) may be responsible for one's vulnerability to psychosis, and, depending on additional syndrome-specific genetic determinants and environmental influences, psychosis may coexist with other clinical characteristics, such as affective symptoms or cognitive dysfunction (Ivleva et al., 2008). Similarly, although some environmental exposures can play a role in a subgroup of people with psychosis, other forms of psychosis may be due to other risk factors such as genetic ones. A prior study that has been recently published in this Journal has highlighted the opportunities that genetics provides to guide psychiatric epidemiology, and vice versa (Danese, 2008). Studies on other disorders suggest that this interplay is even more sophisticated. Recent findings on Alzheimer's disease (AD), are interesting in this regard. To explain the etiology of $\mathrm{AD}$, and determine when the disease process actually starts and how long it takes for its puzzle di cui non conosciamo la figura disegnata sul coperchio della scatola:

i) come possono interagire la ricerca in ambito genetico e quella in ambito epidemiologico per affinare la nostra comprensione dei veri "fenotipi" che caratterizzano i disturbi psichici e, forse, contribuire a mettere a punto classificazioni più affidabili dei disturbi psichici stessi?

ii) come possono contribuire i dati ottenuti dalla ricerca in genetica ed epidemiologia a conoscere le interazioni che hanno luogo fra geni ed ambiente e, quindi, a comprendere come l'ambiente potrebbe essere modificato al fine di prevenire l'insorgenza o migliorare l'esito dei disturbi psichici?

iii) quali sono i contributi più attuali, e le specifiche metodologie, che possono maggiormente aiutarci a comprendere il quadro generale (cioè, la figura disegnata sul coperchio della scatola) dell'eziopatognesi dei disturbi psichici e mettere a punto trattamenti maggiormente mirati?

Come sottolineato nell'Editoriale di Tosato \& Lasalvia (2009), la mancanza di coerenza e di replicabilità di molti dati ottenuti nell'ambito della ricerca genetica sulla schizofrenia può dipendere dalle caratteristiche intrinseche del fenotipo diagnosticato come "schizofrenia". Il fallimento nel dimostrare l'esistenza di un processo unitario ha favorito la concettualizzazione della schizofrenia come sindrome clinica eterogenea per patofisiologia, fenomenologia clinica ed esiti. La correlazione fra queste diverse componenti non è tuttavia, a tutt'oggi, ben compresa e questo ha certamente frenato il progredire di studi che portassero ad una buona comprensione della reale natura di questo disturbo (Peralta \& Cuesta, 2003).

Questa eterogeneità ha portato ad una critica della definizione stessa di schizofrenia data dal DSM-IV. È da rilevare che queste critiche non riguardano solo la schizofrenia; in generale, tutta la genetica psichiatrica ha risentito sia dei limiti legati ad una imprecisa definizione dei "fenotipi e della loro variabilità (Craddock et al., 2008) che della mancanza di conoscenze sugli aspetti neuropatologici e sui fattori ambientali (Kennedy et al., 2003).

Come citato da Tosato \& Lasalvia (2009), l'interazione fra fattori genetici ed ambientali (van Os et al., 2008), può essere ritenuta responsabile di una generica vulnerabilità alle psicosi. A seconda di aggiuntivi fattori sindrome-specifici di tipo genetico od ambientale, la psicosi può essere caratterizzata da componenti cliniche specifiche, quali sintomi affettivi e disturbi cognitivi. Allo stesso modo, è possibile che, mentre l'esposizione a qualche specifico fattore ambientale possa giocare un ruolo importante per un gruppo di persone affette da psicosi, altre forme di psicosi siano invece legate a fattori di rischio di 
pathobiochemical processes to develop, a Latent Earlylife Associated Regulation (LEARn) model has been recently proposed, which postulates that the latent expression of specific genes is triggered at the developmental stage. This model integrates the neuropathological features (e.g., amyloid-loaded plaques) and environmental factors (e.g., diet and hormones) that are associated with the disease. Environmental agents influence gene regulation over the long-term, beginning at early developmental stages, but this influence does not affect pathological outcomes until significantly later in life (Lahiri et al., 2008). Observing these interactions and their modulation throughout life-time can provide better understanding not only of the etiopathogenesis of mental disorders, but also of the actions that should be prioritized to favour healthier lifestyles and create safer environments.

In their Editorial, Day et al. (2009) suggest that the research and treatment of both eating disorders (anorexia and bulimia nervosa) and obesity - disorders that typically are considered as separate entities - would be better understood by a more finely tuned appreciation of the psychosocial components of obesity and the biological and genetic components of eating disorders. According to them, these diseases would result from a complex mixture of genetic and environmental factors, many of which are shared, and some that are preferential between phenotypes. Their findings also show that not only the boundaries between the different mental disorders as currently classified in DSM-IV and between "general medical conditions" and mental disorders are less clear-cut than actually thought, and that cross-disciplinary interaction is a fundamental tool in this sense too.

Consistent with the necessity to develop across-diagnostic entities and inter-disciplinary approaches, the Editorial by Rujescu \& Collier (2009) suggests that the identification of genetic vulnerability factors should involve a comprehensive survey of the entire human genome, and an exploration of the potential role of new, fascinating technologies, such as high-density genetic maps for genome-wide association analyses. Genome-wide association studies have provided proof of principle and yielded several genes that are strongly associated with complex diseases or traits including, on one end of the spectrum, Crohn's disease, diabetes and nicotine dependence, and schizophrenia and bipolar disorder, on the other.

New developments in genetics include also the study of rare genetic variations - in contrast to common genetic variants, such as gene's polimorphisms, which have minor effects in enhancing the risk of developing schizophrenia - that have large effects and may account for a significant number of schizophrenia cases that somehow have been neglected. In the past several years genomic technologies, that isolate gain or loss of genomic seg- tipo genetico. Un articolo pubblicato di recente su questa rivista ha messo in luce le opportunità che la genetica può offrire per guidare l'epidemiologia psichiatrica, e viceversa (Danese, 2008). Studi effettuati in altri ambiti della medicina inducono a supporre un'interazione ancor più sofisticata fra geni ed ambiente. Alcuni dati ottenuti di recente nell'ambito della ricerca sulla Demenza di Alzheimer (DA) sono di grande interesse al riguardo. Per spiegare l'eziologia dell'Alzheimer, e per comprendere quando davvero inizi il processo patologico e quanto tempo richieda per svilupparsi, è stato proposto un modello, denominato Latent Early-life Associated Regulation (LEARn) model che postula una espressività genica latente che verrebbe attivata durante lo sviluppo. Questo modello pare in grado di integrare il ruolo dei fattori neuropatologici (quali la presenza di corpi amiloidi) ed ambientali (quali dieta ed assetto ormonale) che risultano essere associati con il disturbo. I fattori ambientali influenzerebbero la regolazione dell'espressività genica a lungo termine, che inizierebbe in una fase precoce dello sviluppo, senza tuttavia manifestazioni patologiche evidenti sino ad una età più tardiva (Lahiri et al., 2008). Comprendere queste interazioni e la modulazione che ha luogo nel lungo periodo può costituire una chiave interpretativa non solo dell'eziopatogenesi dei disturbi psichici ma anche per l'individuazione di iniziative da attuare in maniera prioritaria per favorire stili di vita più sani e creare ambienti più sicuri.

Day et al. (2009) nel loro Editoriale suggeriscono che una serie di quesiti scientifici e terapeutici inerenti sia $i$ disturbi del comportamento alimentare (anoressia e bulimia nervosa) che l'obesità - disturbi che in genere sono considerati entità separate - verrebbero meglio affrontati da una più fine valutazione, da un lato, delle componenti psicosociali dell'obesità, e, dall'altro lato, degli aspetti biologici e genetici dei disturbi del comportamento alimentare. Secondo gli Autori, tali disturbi risulterebbero da un mix complesso di elementi di tipo genetico ed ambientale, molti di questi condivisi e alcuni in grado di differenziare i due fenotipi. Questi risultati indicano che non solo i confini fra i diversi disturbi psichici come ora classificati nel DSM-IV, ma anche il confine fra le "condizioni mediche generali" e i disturbi psichici può essere meno netto di quanto si pensi attualmente e che l'approccio trans-disciplinare può essere uno strumento fondamentale anche in questo caso.

In linea con la necessità di favorire un approccio transdiagnostico e trans-disciplinare, l'Editoriale di Rujescu \& Collier (2009) raccomanda che l'identificazione dei fattori di suscettibilità genetica si avvalga anche di analisi estensive dell'intero genoma ed esplori il possibile ruolo di nuove tecnologie, quali le high-density genetic maps, per analisi che coinvolgano l'intero genoma. Studi di

Epidemiologia e Psichiatria Sociale, 18, 2, 2009 
ments, have made it possible to detect specific deletions (DNA copy number variants), which most recently have been identified in a wide phenotypic spectrum including not only schizophrenia but also minor dysmorphic features, abnormal EEG, significant expressive language deficits, and in some neuropsychiatric disorders including autism spectrum disorder, ADHD, anxiety disorder, mood disorder and cognitive impairment varying from moderate mental retardation to normal IQ with learning disability.

In conclusion, the findings that are discussed in the three Editorials of this Issue of EPS raise many fascinating new clinical and scientific questions, especially with regard to the boundaries between the different mental disorders and between mental and physical disorders according to the classification and modes of inheritance, shedding new light on the relationship between human behaviour and biological and psycho-social risk factors and on the implications of this new information in improving prevention initiatives, diagnostic tools and treatment strategies.

\section{REFERENCES}

Craddock N., O’Donovan M.C. \& Owen M.J. (2008). Genome-wide association studies in psychiatry: lessons from early studies of non-psychiatric and psychiatric phenotypes. Molecular Psychiatry 13, 649-653.

Danese A. (2008). Genetic opportunities for psychiatric epidemiology: on life stress and depression Epidemiologia e Psichiatria Sociale 17 201-210.

Day J., Ternouth A., Collier D.A. (2009). Eating disorders and obesity: two sides of the same coin? Epidemiologia e Psichiatria Sociale 18, 96-100.

Hough C.J. \& Ursano R.J. (2006). A guide to the genetics of psychiatric disease. Psychiatry 69, 1-20.

Kennedy J.L., Farrer L.A., Andreasen N.C., Mayeux R. \& St GeorgeHyslop P. (2003). The genetics of adult-onset neuropsychiatric disease: complexities and conundra? Science 302, 822-826.

Lahiri D.K., Zawia N.H., Greig N.H., Sambamurti K. \& Maloney B. (2008). Early-life events may trigger biochemical pathways for Alzheimer's disease: the "LEARn" model. Biogerontology 6, 375-379.

Peralta V. \& Cuesta M.J. (2003). The diagnosis of schizophrenia: old wine in new bottles. International Journal of Psychology and Psychological Therapy 3, 141-152.

Rujescu D. \& Collier D. (2009). Dissecting the many genetic faces of schizophrenia. Epidemiologia e Psichiatria Sociale 18, 91-95.

Tosato S. \& Lasalvia A. (2009). The contribution of epidemiology to defining the most appropriate approach to genetic research on schizophrenia. Epidemiologia e Psichiatria Sociale 18, 81-90.

van Os J., Rutten B.P. \& Poulton R. (2008). Gene-environment interactions in schizophrenia: review of epidemiological findings and future directions. Schizophrenia Bulletin 34, 1066-1082. associazione genome-wide hanno confermato l'utilità di questo approccio e individuato vari geni che si associano a disturbi complessi o a tratti che includono, da un lato, Morbo di Crohn, diabete, dipendenza da nicotina e, dall'altro, schizofrenia e disturbo bipolare.

Nuovi sviluppi della genetica includono anche lo studio della variazioni genetiche rare che - al contrario delle variazioni geniche più comuni, quali i polimorfismi genici, che hanno un effetto minimale nell'aumentare il rischio di sviluppare schizofrenia - risultano avere un effetto sostanziale e possono essere ritenute responsabili di un numero di casi di schizofrenia di origine fino ad ora sconosciuta. Negli ultimi anni, una serie di tecniche genetiche in grado di individuare segmenti di genoma deleti o aggiuntivi, hanno reso possibile l'identificazione di delezioni (denominate DNA copy number variants), riscontrate nel genoma di soggetti con un ampio spettro di fenotipi, inclusivi non solo della schizofrenia, ma anche di dimorfismi minori, anomalie EEG, deficit del linguaggio. Tali delezioni sono stati riscontrate anche il alcuni disturbi neuropsichiatrici quali autismo, ADHD, disturbi d'ansia e dell'umore, disturbi cognitivi di diversa gravità, dal franco ritardo mentale a un quoziente intellettivo nella norma, in soggetti con qualche difetto di apprendimento.

In conclusione, i dati discussi nei tre Editoriali riportati in questo numero di EPS pongono una serie di nuovi, affascinanti quesiti clinici e scientifici, che riguardano specialmente il confine fra i diversi disturbi psichici e fisici, così come ora classificati, la loro ereditarietà, e gettano nuova luce sulla relazione fra comportamento, fattori di rischio biologici e psicosociali e sulle implicazioni che questo nuovo tipo di informazioni può avere per migliorare le iniziative di prevenzione, gli strumenti diagnostici e le strategie terapeutiche. 